\section{Growing North Minneapolis: Connecting Youth and Community through Garden-based Experiential Learning}

\author{
Mary Rogers ${ }^{1}$, Illana Livstrom ${ }^{2}$, Brandon Roiger $^{3}$, \\ and Amy Smith ${ }^{3}$
}

ADDITIONAL INDEX WORDS. community gardens, horticultural education, urban horticulture, youth development

Summary. Growing North Minneapolis (GNM) is an urban agriculture and youth development summer program sited in the North Minneapolis, MN, neighborhood. The program is a university-community partnership between faculty at the University of Minnesota (UMN) and North Minneapolis community partners. We leverage resources from the city of Minneapolis Step-Up program to recruit, train, and employ youth (14-15 years old) who face barriers to employment-particularly youth from low-income families, youth of color, youth from immigrant families, and youth with disabilities. Youth interns are placed in a 10-week-long summer program and are matched with undergraduate student mentors from the UMN and North Minneapolis gardener mentors. The undergraduate students and garden mentors work together to lead teams of youth and work in multiple urban garden sites located in North Minneapolis, a designated low-resource community in the metro area. One of our goals is to develop leadership experience for UMN undergraduate students and improve food and horticultural skills among urban youth through garden-based education. Learning is experiential and contextualized in the various community garden sites through activities focused on food justice and accessibility, food production systems, and horticultural science. Youth learning and development outcomes are reported based on written postprogram qualitative survey questions prompting youth to identify what they learned throughout the program, what they enjoyed the most, and what challenged them after the summer program in 2018. Our results show that youth participants learned across multiple domains of knowledge and valued the social interaction offered by the in-

tergenerational mentorship structure. The GNM program can serve as a model for garden-based experiential learning with early high school youth.

$\mathrm{G}$ lobally, $55 \%$ of people reside in urban areas where access to nature is limited by the built environment (United Nations Department of Economic and Social Affairs, 2018). Consequently, food skills such as growing food, meal planning, food preparation, willingness to try new foods, and general food systems knowledge is eroding as people reside farther away from agriculture. Lack of exposure and access to healthy foods such as fruits and vegetables results in limited consumption. As a result, people may choose fast, processed, and convenient foods, and can suffer negative diet-related consequences. Improving access to healthy foods and opportunities to develop food skills, such as growing and preparing food, has been shown to increase attitudes toward and preferences for these foods (Heim et al., 2009). In urban areas, this can be achieved through schoolyard and community gardens.
There is growing interest in the benefits of urban agriculture for youth education as evidenced by the schoolyard garden movement. Garden-based experiential learning activities are increasingly being used in schools to improve youth attitudes toward healthy foods and exercise, to help develop environmental awareness and enhance academic learning, and to promote personal and social development (Blair, 2009). However, these programs are typically targeted toward grades kindergarten through fifth grade and are more prevalent in high-resource communities (Rogers, 2018). Few garden-based models are available for engaging young teens. Consistent opportunities for engagement would undoubtedly reinforce the positive attributes associated with garden-based education and should be available to youth as they age.

North Minneapolis, MN, or the "Northside," is a diverse and ment throughout childhood develop- culturally rich geographic area in the northwest section of Minneapolis, $\mathrm{MN}$. This area is composed of 15 distinct neighborhoods and is home to 60,000 residents. North Minneapolis has a history of targeted economic disinvestment and racial segregation. As a result of this inequity, a number of issues remain salient to this community, including employment opportunities, access to healthy foods, access to quality healthcare, and public health and safety (University of Minnesota Center for Urban and Regional Affairs, 2018). North Minneapolis has twice the poverty rate of the City of Minneapolis as a whole and struggles with a host of disparities related to access to educational opportunities and career pathways. Based on 2010 city census data, Northside community residents identified as $57 \%$ black or African American, compared with $18 \%$ for the City of Minneapolis as a whole. Asian and Pacific Islanders make up $17 \%$ of the community, compared with $5.6 \%$ citywide (Minnesota Compass, 2019). In addition, $40 \%$ of the community is below poverty level, compared with $20 \%$ citywide. This community is designated as food insecure based on low income and lack of availability of nutritious food (U.S. Department of Agriculture, 2017). The GNM program is an example of a communitydriven effort to help alleviate some of these issues through youth education and outreach connected to urban agriculture in Northside community gardens.

Experiential learning and learning outside the classroom activities are considered important to develop the "whole child" (Malone, 2008). A review of the current literature shows that these experiences help youth learn, improve social interactions, contribute to emotional well-being, provide opportunities for physical activity, and promote better behavioral responses (Malone, 2008). Experiential learning is defined as "a process that develops knowledge, skills and attitudes based on consciously thinking about an experience. Thus, it involves direct and active personal experience combined with reflection and feedback." (Malone, 2008). Garden-based experiential learning opportunities can be adapted to serve the needs of young teens in urban areas and can continue to reinforce or 
introduce food skills while also developing workforce skills, professional development, and personal agency, and simultaneously provide a pathway to college. In our program, we combine garden-based experiential learning with an out-of-school summer program that provides youth with paying jobs and the ability to build professional skills. This article outlines the GNM summer program as a case study for intergenerational mentorship that includes gardenbased learning with older youth (14-15 years old). We provide examples of student learning that took place as an outcome of the 10 -weeklong summer program in 2018 and highlight successes and challenges experienced by youth.

\section{Growing north Minneapolis}

Founded in 2017, the GNM partnership emerged from a community-university partnership funded by the UMN Healthy Foods, Healthy Lives Institute to address some of the issues centered on development of food skills and community gardening, and to create additional workforce and career opportunities for Northside youth within an intergenerational mentorship structure. We

Received for publication 6 Feb. 2019. Accepted for publication 7 May 2019.

Published online 17 September 2019

${ }^{1}$ Department of Horticultural Science, University of Minnesota, 305 Alderman, 1970 Folwell Avenue, St. Paul, MN 55108

${ }^{2}$ Department of Curriculum and Instruction, University of Minnesota, 159 Pillsbury Drive SE, Minneapolis, MN 55455

${ }^{3}$ Agricultural Education, Communication and Marketing, University of Minnesota, 146 Ruttan Hall, 1994 Buford Avenue, St. Paul, MN 55108

Funding for this program was provided by the Greater Twin Cities United Way Full Lives grant program (funded in 2017-18).

We honor Michael Chaney, Patsy Parker, Ron McConico, and Karl Hakanson for their vision and leadership in creating the foundation of the Growing North Minneapolis (GNM) program and for continued guidance and support of the program. We honor Northside garden mentors and members of the current GNM leadership team: Paul Mitchell, Candis McKelvy, Beverly Stancile, JoAnn Ulm, Clifton Williams, and Luna Zeidner.

This paper is a part of a workshop titled "Urban Horticulture: From Local Initiatives to Global Success Stories" that was presented 3 Aug. 2018 during the American Society for Horticultural Science annual conference in Washington, DC.

M.R. is the corresponding author. E-mail: roge0168@ umn.edu.

This is an open access article distributed under the CC BY-NC-ND license (https://creativecommons.org/ licenses/by-nc-nd/4.0/).

https://doi.org/10.21273/HORTTECH04308-19 focus on the intersection of youth with the Northside community. Our collaboration includes Northside residents and gardeners; community leaders; and faculty, staff, and students in the UMN College of Food, Agriculture, and Natural Resource Sciences (CFANS) as well as the UMN Extension. Our goal is to develop a regenerative environment that fosters curiosity, future dreams, life skills, and career and educational opportunities with the North Minneapolis community. Our 10-week-long summer program uses intergenerational mentorship and urban agriculture to advance environmental, social, and racial justice in North Minneapolis. The GNM was tested in 2017 , our first "pilot year" of the program. In 2018, our summer program ran from 11 June to 17 Aug.

\section{Program structure and participants}

The GNM structure consists of five teams of six to seven youth paired with a UMN undergraduate student and a Northside gardener mentor who work together to provide training and supervision of youth throughout the summer program. The recruitment process for youth, UMN undergraduate students, and Northside gardener mentors is described next.

In 2018, the GNM program included 31 youth (age, 14-15 years) recruited through the Minneapolis Step-Up Program. The Step-Up program is one of the nation's leading youth employment programs and supports historically underrepresented youth in Minneapolis by providing professional training, and places youth with local employers (City of Minneapolis, 2019). The Step-Up program interviewed and assigned youth to our program in the spring (Fig. 1). Youth identified their interests during the Step-Up application process and were matched to our program based on these interests and the job description GNM provided. The Step-Up program provided wages for all youth participants, at $\$ 9.60 / \mathrm{h}$ for $25 \mathrm{~h} /$ week, and issued bus passes so youth could take public transportation to their garden sites. According to an intake survey provided on the first day of the program, the youth participants in our program in 2018 were $58 \%$ female and $42 \%$ male, and $72 \%$ of them self-identified as African-American, 19\% identified as white/European American, 2\% identified as Asian, 3\% identified as Hispanic or Latinx, and $2 \%$ identified as multiracial. The majority (79\%) of the youth participants indicated they lived in North Minneapolis; 21\% did not reside in this area. Roughly half the participants indicated at least one of their parents lived outside the United States.

Undergraduate student mentors were recruited by faculty and a doctoral student in CFANS. Student applicants went through an interview and selection process in Feb. 2018. The UMN undergraduate students were all enrolled in CFANS from various programs. Four of the six undergraduates identified education as a career interest and were either enrolled in agricultural education or environmental education programs. All the undergraduate students had at least some previous gardening experience (i.e., one summer or season of gardening-related work); however, experience varied by individual. Experience and interest in youth development and education was prioritized over horticultural experience, and undergraduate students were paired with gardener mentors who had practical gardening experience. Novice undergraduate gardeners were paired intentionally with more experienced gardener mentors. Before the summer program, undergraduate students participated in a 7 -week-long, 2 -credit course (AFEE 3480: Growing North Ag \& Food Systems Education) during the spring semester that allowed them to meet Northside gardeners and program collaborators, familiarize themselves with garden sites and the North Minneapolis community, and prepare them for mentorship. The role of undergraduate mentors was to serve as a bridge for the youth to the university and higher education, and to connect with youth as near-peers. The UMN undergraduates gained college credit and practical professional experience as a part of this program, and were supervised by faculty and the doctoral student who served as summer program director. Weekly check-in meetings were held with undergraduate mentors to monitor progress of program 


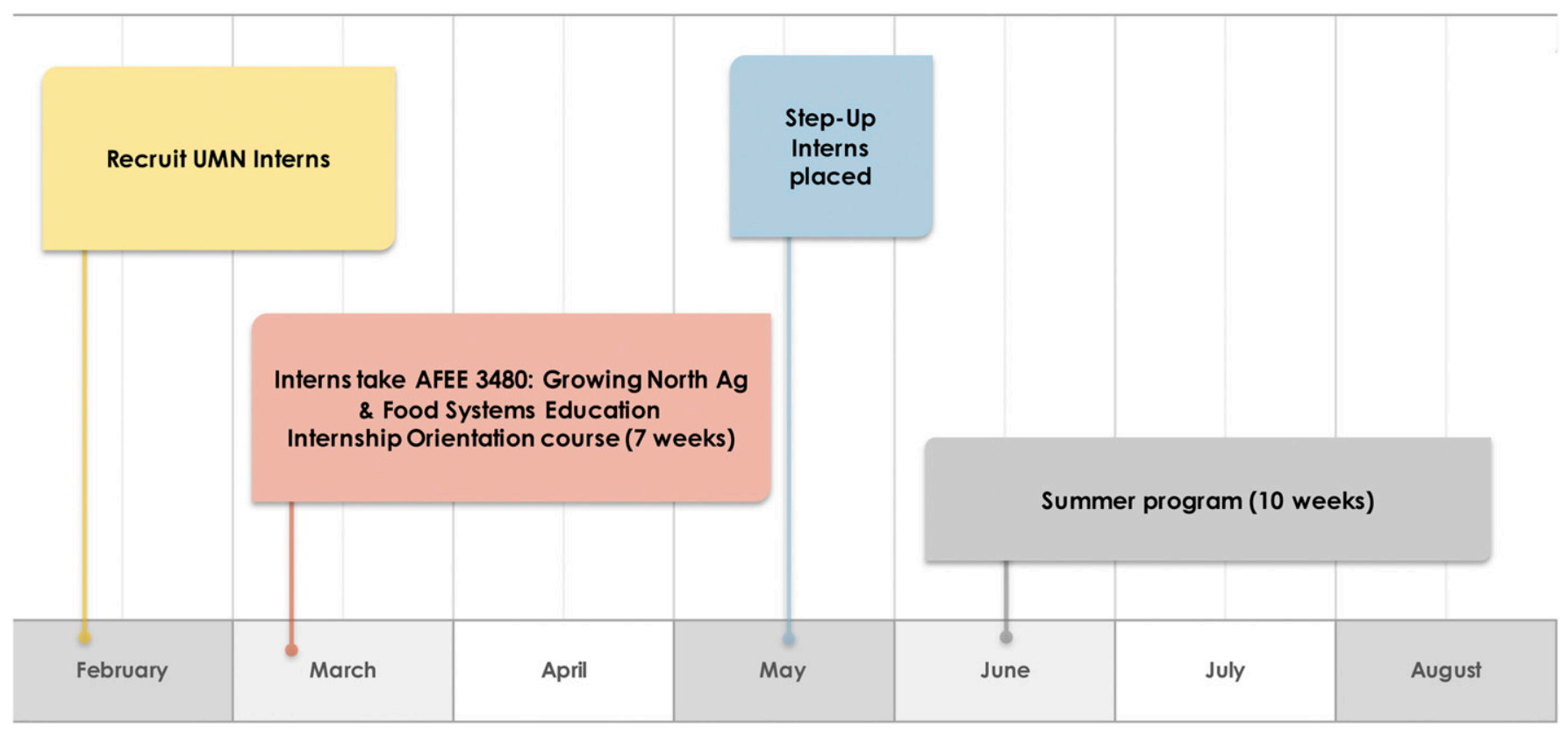

Fig. 1. The Growing North Minneapolis program timeline in 2018. Agriculture, Food, and Environmental Education (AFEE) 3480 is a course taught at the University of Minnesota (UMN).

goals, share knowledge and experiences, and troubleshoot challenges. UMN undergraduate student mentors were compensated $\$ 13 / \mathrm{h}$ for 25 $\mathrm{h} /$ week for their participation in the summer program.

Six Northside gardener mentors committed to working in garden teams alongside UMN undergraduate students through the duration of the program. These mentors were identified by a project partner and community organizer with longstanding ties in the community, and were older neighborhood residents active in the community and had experience gardening. They chose to participate based on their interest in community gardens and working with youth. The role of these mentors was multifold. We recognized the need for Northside gardeners to serve as a bridge for the university to the community, and to provide perspective and context to the place-based gardening program. In addition, we relied on Northside garden mentors to provide basic horticultural and gardening knowledge based on their years of practical experience. Northside gardener mentors were compensated at $\$ 15 / \mathrm{h}$ for $20 \mathrm{~h} /$ week. Salaries for the UMN undergraduate students and Northside gardeners were paid via funding from the Greater Twin Cities United Way Full Lives grant program.

\section{Program activities}

The five garden teams (six to seven youth per team, plus UMN undergraduate mentor and Northside gardener mentor) were responsible for the care and maintenance of 14 preexisting community garden sites in North Minneapolis. Garden sites varied in structure and function. Some of these gardens include leased, allotment-style plots where neighborhood residents also garden, whereas other sites were vacant, city-owned lots recently allocated as garden sites. Produce was distributed in multiple ways, and was harvested and used for lunches during the program. Some gardens were maintained for members of the community to harvest; others operated as neighborhood market gardens and produce was sold at farmers' markets in the community. GNM garden teams were responsible for general garden tasks including soil and bed preparation, transplanting, seeding, weeding, irrigating, harvesting, trellising, and cultural pest management practices. We took an informal, adaptive approach to introduce environmental and science content because we experienced pushback from youth during the pilot year (2017) when the program felt too "school-like." Thus, content learning was different for each group depending on the interests of each group. We adopted a youth-led participatory action research (YPAR) framework to encourage each of the five garden teams to dive deeper into any of these garden-related concepts through the development of special projects (University of California Regents, 2015). YPAR is defined as "an innovative approach to positive youth and community development based in social justice principles in which young people are trained to conduct systematic research to improve their lives, their communities, and the institutions intended to serve them" (University of California Regents, 2015). We used this approach because it aligns directly with our mission of promoting youth selfdetermination with an equity focus. In addition, each team prepared meals collectively and participated in cooking demonstrations on a weekly basis, using produce harvested from the gardens, based on feedback received during our pilot year.

\section{Program outcomes and evaluation}

For the YPAR, each group chose a different project that reflected the various interests of the members of the group related to urban agriculture and the natural environment. During their research process, youth drew largely on the knowledge, skills, and experience of their community and 
Table 1. Domains of knowledge and youth (age, 14-15 years) responses to the open-survey question "Describe three things you learned this summer" at the conclusion of the Growing North Minneapolis summer program in 2018 ( $n=20$ youth).

\begin{tabular}{|c|c|c|}
\hline $\begin{array}{l}\text { Domains of } \\
\text { knowledge }\end{array}$ & $\begin{array}{l}\text { Responses } \\
\text { (no.) }\end{array}$ & Example of youth response \\
\hline Psychomotor & 14 & How to plant vegetables \\
\hline Psychomotor & 7 & How to weed properly \\
\hline $\begin{array}{l}\text { Cognitive and } \\
\text { affective }\end{array}$ & 7 & How to eat healthy \\
\hline Cognitive & 3 & How to identify each plant \\
\hline Psychomotor & 2 & How to water \\
\hline Cognitive & 2 & You can compost almost anything \\
\hline Affective & 2 & I learned more about communication \\
\hline Cognitive & 2 & $\begin{array}{l}\text { How the animals and insects } \\
\text { help with the plants }\end{array}$ \\
\hline Cognitive & 1 & Aquaponics \\
\hline Cognitive & 1 & I learned plants have medical uses \\
\hline Affective & 1 & Gardening is fun \\
\hline Cognitive & 1 & $\begin{array}{l}\text { Farmers use pesticides and genetically } \\
\text { modified organisms }\end{array}$ \\
\hline Cognitive & 1 & What plants go well together \\
\hline Affective & 1 & $\begin{array}{l}\text { Community is the cornerstone } \\
\text { of community gardening }\end{array}$ \\
\hline Psychomotor & 1 & How to harvest \\
\hline Cognitive & 1 & New birds I didn't know before \\
\hline Affective & 1 & I learned how to be more patient \\
\hline Affective & 1 & Open up to people \\
\hline Affective & 1 & I learned how to ask more questions \\
\hline Affective & 1 & I learned more about teamwork \\
\hline Affective & 1 & Controlling my attitude \\
\hline Affective & 1 & How to take responsibility \\
\hline $\begin{array}{l}\text { Cognitive and } \\
\text { affective }\end{array}$ & 1 & Food justice \\
\hline Psychomotor & 1 & How to ride the bus \\
\hline
\end{tabular}

university undergraduate mentors, and additional experts in the program and in the community. They also researched their respective research topics at the local library and at the local community school's computer laboratory, and by using their personal devices. To support their projects further, youth attended a session provided by UMN librarians about organizing and presenting findings through different modalities. At the conclusion of the 10 -week-long summer program, all five garden teams presented their YPAR projects at the end-of-program picnic. Examples of these projects included learning about composting and making posters that connect composting to urban gardening; learning about growing small fruit in gardens; learning about local birds and their interaction with the North Minneapolis community gardens, including construction of homemade bird feeders and booklets outlining important biological and ecological facts of common birds in Minnesota; a gardening 101 how-to guidebook on urban gardening, including information on companion planting and soil chemistry; and a needs-assessment project that included interviews of community members for a redesign of a preexisting garden site. To evaluate student learning, we used a written postprogram survey that included three openended questions, administered by paper during the last week of the summer program. These questions prompted youth to write about l) three things they learned over the course of the program (Table 1), 2) what experiences they enjoyed the most (Table 2), and 3 ) what they found most challenging (Table 3 ). We received 20 completed surveys out of 30 total youth participantsa $66 \%$ response rate. Reasons for this discrepancy were that some youth dropped out of the program, some were absent on the day surveys were administered, and some did not complete the survey. Youth responses were sorted by theme and counted to assess the most frequent responses. Direct quotes were pulled from the responses as an example of youth voices.

It is evident from the youth responses that the YPAR projects, physical practice of the gardening work, and weekly cooking activities contributed most to their learning. Youth learning is reported in Table 1 , and responses are categorized into the three main domains of learning (Anderson et al., 2001). These include the cognitive domain, which is demonstrated by recalling knowledge, organizing ideas, analyzing ideas, and applying knowledge; the affective domain, which is demonstrated by behaviors and attitudes including showing increased awareness, listening, and responding; and the psychomotor domain, which is demonstrated by physical and kinesthetic skills. Youth reported learning across all three domains, with 10 responses linked to the cognitive domain, 11 linked to the affective domain, and five responses linked to the psychomotor domain. Youth predominantly listed learning how to plant, garden, and grow food as an outcome of the summer program with 14 total responses in this theme (Table 1 ). The second most frequent learning outcomes listed were weeding and healthy meal preparation, with seven responses each. Plant identification was listed by three youth, and two respondents each listed composting, irrigating, and biotic interactions ( $\mathrm{Ta}$ ble 1). These responses show that most of the learning identified by participants was in the form of knowledge and skill acquisition of "food skills," including gardening and cooking, which were central to our program. A number of other themes related to food skills were listed infrequently, including aquaponics, medicinal uses of plants, pesticides and genetically modified organisms, companion planting, and harvesting. It is also evident that youth participants benefited socially from participation in the 10-week-long program. Two respondents identified enhanced ability to communicate as an outcome of the program, and less frequent social 
Table 2. Youth (age, 14-15 years) responses to the open-survey question "What did you enjoy most about the program?" at the conclusion of the Growing North Minneapolis summer program in $2018(n=20$ youth $)$.

\begin{tabular}{|c|c|c|}
\hline $\begin{array}{l}\text { Enjoyment } \\
\text { factor }\end{array}$ & $\begin{array}{l}\text { Responses } \\
\text { (no.) }\end{array}$ & $\begin{array}{l}\text { Example of } \\
\text { youth response }\end{array}$ \\
\hline Gardening & 9 & $\begin{array}{l}\text { Learning how to garden because I didn't know } \\
\text { how to do that before }\end{array}$ \\
\hline Social aspects & 9 & $\begin{array}{l}\text { I enjoyed meeting new friends and good } \\
\text { experiences were made. I enjoyed the company } \\
\text { and the people I've met. }\end{array}$ \\
\hline Learning & 7 & $\begin{array}{l}\text { Learning new things because now I can } \\
\text { go home and help my mom out with her garden }\end{array}$ \\
\hline Plant identification & 3 & Learning a plant from a weed \\
\hline Harvesting & 2 & $\begin{array}{l}\text { The harvesting because I get to bring the plant } \\
\text { home }\end{array}$ \\
\hline $\begin{array}{l}\text { Cooking and } \\
\text { eating }\end{array}$ & 2 & The food because it was good \\
\hline The money & 1 & The money \\
\hline Working outside & 1 & Working outside with teammates \\
\hline
\end{tabular}

Table 3. Youth (age, 14-15 years) responses to the open-survey question "What did you find most challenging?" at the conclusion of the Growing North Minneapolis summer program in $2018(n=20$ youth $)$.

\begin{tabular}{|c|c|c|}
\hline $\begin{array}{l}\text { Challenge } \\
\text { factor }\end{array}$ & $\begin{array}{l}\text { Responses } \\
\text { (no.) }\end{array}$ & $\begin{array}{c}\text { Example of } \\
\text { youth response }\end{array}$ \\
\hline $\begin{array}{l}\text { The weather/ } \\
\text { the heat }\end{array}$ & 10 & The heat because it was hot and hard to work \\
\hline $\begin{array}{l}\text { Social } \\
\quad \text { interactions }\end{array}$ & 5 & $\begin{array}{l}\text { Talking to people because I can be antisocial } \\
\text { sometimes }\end{array}$ \\
\hline $\begin{array}{l}\text { Plant } \\
\text { identification }\end{array}$ & 2 & Identifying what was a weed and what was a plant \\
\hline Transportation & 2 & $\begin{array}{l}\text { Transportation because if we have to meet } \\
\text { somewhere far, I need to find a ride or figure out } \\
\text { the bus routes }\end{array}$ \\
\hline Weeding & 1 & Weeding all the time because it was very tedious \\
\hline The bugs & 1 & The bugs \\
\hline $\begin{array}{l}\text { Waking up } \\
\text { early }\end{array}$ & 1 & Waking up early \\
\hline Gardening & 1 & Gardening \\
\hline Presentations & 1 & Presentations \\
\hline Learning & 1 & Learning new things \\
\hline
\end{tabular}

benefits identified were patience, teamwork, asking questions, and being “open" to people. There was also evidence that personal and emotional learning was occurring, as one student each identified "controlling my attitude" and "how to take responsibility" as an outcome of the program. Overall social, personal, and emotional benefits were listed less frequently than knowledge and skills in the written survey when youth were prompted to identify "learning." It is likely that these gains are understated from this question based on how it was phrased on the written survey.

When youth participants were prompted to identify what they translate their newly gained skills to their home life-for example ". . . learning how to garden because my mom wants to start a garden" and "now I can go home and help my mom out with her garden." There is some evidence of emotional and personal learning in these statements that indicate pride in the work: ". . . seeing the before and after of our gardens."

When asked to identify the most challenging aspects of the program, most of the participants listed working in the heat (Table 3), with 10 responses. Difficult social interactions were the second most frequently identified challenge, with five respondents. One participant observed tension between program mentors “. . . the power struggle between the supervisors because it also affected the way that my coworkers and I worked in the garden." Transportation was listed by two individuals who indicated difficulty navigating bus routes. Other aspects of the program were listed less frequently, including weeding, insects, gardening, waking up early, presentations, and learning ( $\mathrm{Ta}$ ble 3 ).

\section{Discussion}

The outcomes of our summer program indicate that youth gained basic horticultural knowledge and skills related to food production and preparation, as well as benefited from social interactions with other youth, UMN undergraduate mentors, and Northside garden mentors. Based on youth responses, learning occurred across multiple domains of knowledge, including cognitive, affective, and psychomotor. The strengths of the GNM model are that it embraces intergenerational mentorship for youth development through the inclusion of Northside garden mentors, who were adult citizens older than the 14- to 15-year-old youth participants; and undergraduate students, who were older than the youth participants but still closer in age as "near-peers." Outside-the-classroom programs such as GNM are more complex and provide for different opportunities for learning and development for participants. There are very few examples of garden-based programs for youth ages 14 to 15 years old. The Garden Mosaics program connects youth ages 9 to 18 years old to urban community gardens (Krasny and Tidball, 2009). 
This program was originally developed at Cornell University and has been adopted nationwide by not-for-profit organizations, faith-based institutions, and others. Research from the Garden Mosaics program indicates that providing experienced adult mentors to youth in community garden programs allows for the transition of youth from passive observers to novice participants and helps facilitate a "community of practice" around gardening (Krasny and Tidball, 2009). In addition, including multiple participants with different perspectives and knowledge systems working together to manage a specific area such as community gardens is a form of adaptive comanagement and can enhance social and personal learning for all participants (Krasny and Tidball, 2009). Adolescence is a vulnerable developmental stage characterized by emotional, social, and biological changes; exposure to nature may offer a therapeutic effect (Lee et al., 2004).

The primary challenge faced by the GNM program is the dependence on external funding through grants to compensate the UMN undergraduate and Northside gardener mentors for their work. The youth participants are compensated through the City of Minneapolis Step-Up program. Eventually, sales from produce and other agricultural goods could be used to subsidize GNM; however, it is not realistic to expect this source of revenue to offset the costs of labor because the program is—-first and foremost-a development program focused on underserved youth and is not optimized toward efficiency and economics of food production. This is not a unique challenge for urban agricultural organizations that primarily serve social goals. Program sustainability needs to be based on diversified funding sources, perhaps including donations, gifts, and crowd funding, in addition to programmatic revenue and grants.

\section{Literature cited}

Anderson, L.W., D.R. Krathwohl, P.W. Airasian, K.A. Cruikshank, R.E. Mayer, P.R. Pintrich, J. Raths, and M.C. Wittrock. 2001. A taxonomy for learning, teaching, and assessing: A revision of Bloom's taxonomy of educational objectives. Abridged ed. Pearson Education Group, Boston, MA.

Blair, D. 2009. The child in the garden: An evaluative review of the benefits of school gardening. J. Environ. Educ. 40:15-38.

City of Minneapolis. 2019. Step-Up program. 20 Jan. 2019. <http://www. minneapolismn.gov/cped/metp/stepup_home>.

Heim, S., J. Stang, and M. Ireland. 2009. A garden pilot project enhances fruit and vegetable consumption among children. J. Amer. Dietetic Assn. 109:1220-1226.

Krasny, M.E. and K.G. Tidball. 2009. Community gardens as contexts for science, stewardship, and civic action learning. Cities Environ. 2:1-17.
Lee, Y.-H., M.-R. Ro, and Y.-S. Lee. 2004. Effects of horticultural activities on anxiety reduction of female high school students. Acta Hort. 639:249-251.

Malone, K. 2008. Every experience matters: An evidence-based research report on the role of learning outside the classroom for children's whole development from birth to eighteen years. 19 Mar. 2019. <http://attitudematters.org/ documents/Every\%20 Experience\% 20Matters.pdf $>$.

Minnesota Compass. 2019. Near North neighborhood. 20 Jan. 2019. <https://www. mncompass.org/profiles/neighborhoods/ minneapolis/near-north>.

Rogers, M.A. 2018. Urban agriculture as a tool for youth development, p. 211232. In: D. Nandwani (ed.). Urban horticulture: Sustainability for the future. Springer Nature, Heidelberg, Germany.

United Nations Department of Economic and Social Affairs. 2018. 19 Mar. 2019. <https://www.un.org/development/ desa/en/news/population/2018-revisionof-world-urbanization-prospects.html> .

University of California Regents. 2015. YPAR HUB. 20 Jan. 2019. <http:// yparhub.berkeley.edu>.

University of Minnesota Center for Urban and Regional Affairs. 2018. 19 Mar. 2019. <http://gentrification.umn.edu/ sites/g/files/pua4816/f/general/ northeast-2-23-18.pdf $>$.

U.S. Department of Agriculture. 2017. Food access research atlas. 20 Jan. 2019. <https://www.ers.usda.gov/dataproducts/food-access-research-atlas/>. 